Dept. of Zoology,

Faculty of Science, Assiut University, Assiut, 71516, Egypt.

\title{
GLUCOSE STARVATION INDUCED AUTOPHAGY IS A POTENT APOPTOTIC CELL DEATH MECHANISM IN MULTIDRUG RESISTANT HL60/ADR CELLS
}

(With 4 Figures)

By

A-B.M. ABDEL-SHAKOR

(Received at 15/10/2009)

الالتهام الذاتي الناتج عن صوم الجلوكوز يؤدي إلي موت خلوي مبرمج فعال

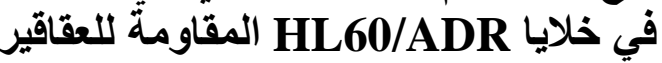

أبو بكر محمد الطبب عبد الشكور

أوضحت الدر اسات أن وصول الخلايا السرطانية إلي حالة مقاومة العقاقير يمثل عقبة كبيرة

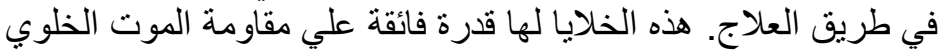

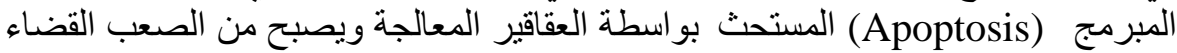

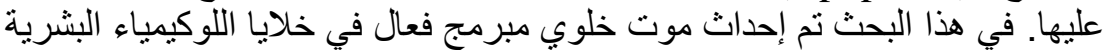

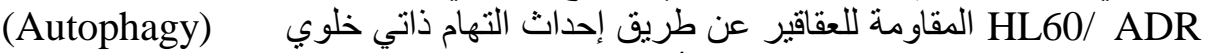

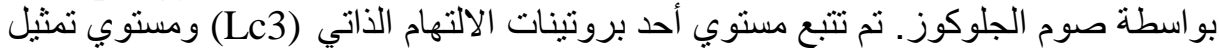
بعض بروتينات الموت الخلوي المبرمج

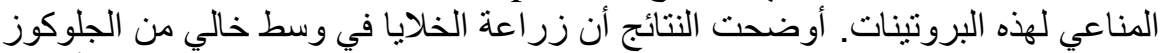

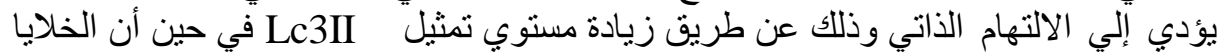

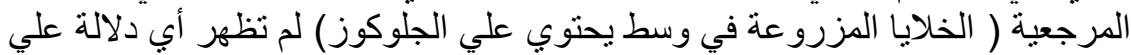

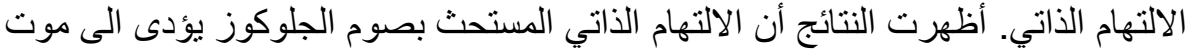

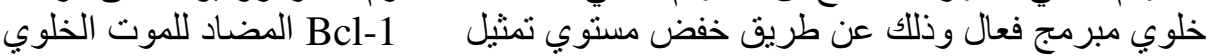

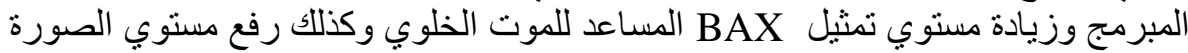

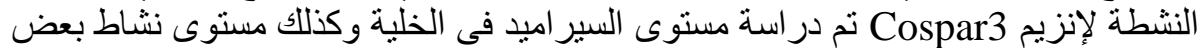

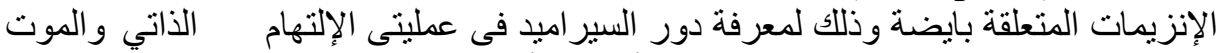

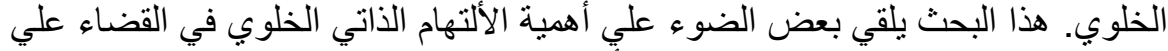

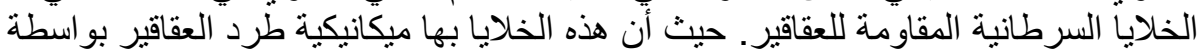

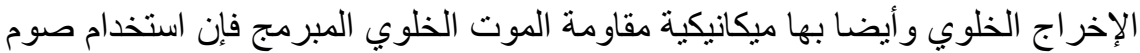

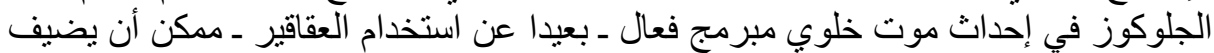

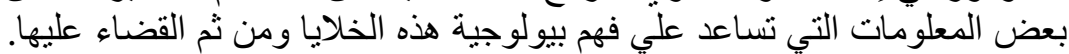

\section{SUMMARY}


Multidrug resistance in cancer is significantly limits the effectiveness of cancer chemotherapy. The main purpose of the present study is to investigate the role of autophagy induced by glucose starvation in apoptosis induction in multidrug resistant human leukemia HL60/ADR cell line. The present data indicates that glucose starvation induced autophagy as determined by the level of LC3 protein (autophagy marker), whereas serum deprivation did not induce autophagy at the same time points. The induction of autophagy by glucose starvation exerted a great effect on apoptosis induction and enhancement. It was found that glucose starvation induced caspase 3 cleavage more intensive than serum deprivation. Also, glucose starvation up-regulated the pro-apoptotic BAX and down-regulated the anti-apoptotic BCL-1 proteins representation, but serum deprivation did not affect both protein levels. The lipid mediator, Ceramide was the most candidate key player in autophagy and/or apoptosis induction after glucose starvation. Accordingly, Ceramide level was determined by DGK assay, ceramide level was elevated after glucose starvation and decreased after serum deprivation. Elevation of Ceramide by glucose starvation was found to be due to down-regulation of sphingomyelin synthase and glucosyl ceramide synthase activities and up-regulation of neutral sphingomyelinase activity. The opposite case of these enzyme activities was obtained in serum deprived cells. The current data throw the light on autophagy induced by glucose starvation as a powerful tool for apoptosis induction in multidrug resistance malignancy.

Abbreviations: SM; sphingomyelin, Cer; Ceramide, DG; Diethyl Glycerol, SMS; Sphingomyelin Synthase, GCS; Glucosyl ceramide Synthase, GCer; Glucosyl Ceramide, ASMase; Acid Sphingomyelinase, NSMase; Neutral Sphingomyelinase, Glu; Glucose, Ser; Serum, MDR; Multidrug Resistance.

Key words: Multidrug resistance, HL60/ADR, ceramide, autophagy, apoptosis, glucose starvation.

\section{INTRODUCTION}

Traditional cancer therapy induces cell death by evoking apoptosis; however, during treatment, some cells acquire drug resistance and develop a mechanism for pumping drugs into the extracellular space. Drug resistant cells become actually apoptotic resistance and become a significant barrier to effective chemotherapy. Other 
mechanisms of cell death have emerged as potential novel mechanisms for cancer therapies to overcome the drug and apoptosis resistant state.

Autophagy is a process that occurs in all cells, and induced in many types of cancer. Autophagy functions as both a cell survival and a cell death mechanism depending on the context and the stimuli, which are likely exploitable for cancer therapy. Autophagy is a general term for the degradation of cytoplasmic components within lysosomes (Cuervo, 2004; Levine and Klionsky, 2004; Shintani and Klionsky, 2004; Klionsky, 2005, 2007; Mizushima and Klionsky, 2007). This process is quite distinct from endocytosis-mediated lysosomal degradation of extracellular and plasma membrane proteins. Several factors can trigger autophagy as nutrient starvation, growth factor deprivation, hypoxia, ionizing radiations or cytotoxic compounds (Wang and Klionsky, 2003). Recently, autophagy was proved to play critical role in cell death and tumor suppression (Mizushima, 2005). Several genes implicated in the signaling cascade of autophagy, LC3 (microtubule associate light chain protein 3 ) is a well known marker for autophagy. It exists in two forms, LC3-I and its proteolytic derivative LC3-II (18 and $16 \mathrm{kDa}$, respectively). LC3-I is localized in the cytosol, whereas LC3-II in autophagosomal membranes. Thus, LC3-II can be used to estimate the abundance of autophagosomes and hence the progress of autophagy before they are destroyed through fusion with lysosomes (Kabeya et al., 2000; Mizushima et al., 2001).

Ceramide (Cer) is a sphingolipid mediator with an essential role in cell growth, cell death, cell proliferation, and stress response (Mathias et al., 1998; Hannun et al., 2001; Levade et al., 2002). Ceramide can be generated and consumed by different metabolic routes (Riboni et al., 1997; Merrill, 2002). It is produced by de novo synthesis in the endoplasmic reticulum or by the hydrolysis of sphingomyelin by acid sphingomyelinases, localized in acidic compartments and neutral sphingomyelinases, localized in the plasma membrane and mitochondria. Ceramide is engaged in the biosynthesis of glucosylceramide (and other complex glycosphingolipids) and of sphingomyelin. Ceramide can also generate ceramide 1-phosphate, sphingosine, and sphingosine 1-phosphate. Sphingosine 1-phosphate is a second messenger that often has an opposite effect to ceramide on biological outcomes (Maceyka et al., 2002).

Apoptotic machinery is composed of at least dozens of antiapoptotic and proapoptotic proteins. The balance of antiapoptotic and proapoptotic proteins contributes to the balance of cell growth and 
cell death. In cancer cells many lines of evidence have shown an imbalance with elevated antiapoptotic and reduced proapoptotic activities. One way or another were reported to explain this including: 1) overexpression of antiapoptotic proteins (Bcl-2, Bcl-xL, Mcl-1, c-FLIP, inhibitors of apoptosis, and heat shock proteins), 2) mutations of proapoptotic proteins ( $\mathrm{p} 53$, Apaf-1, Bax, FAS, Fas-associated protein with death domain, and caspase), and 3) loss of caspases as caspase-3 and caspase-8 (Stavrovskaya, 2000; Hersey and Zhang, 2003; Pommier et al., 2004; Longley and Johnston, 2005). In addition, the apoptotic pathways in cancer cells are affected by many oncogenic signals (Blagosklonny, 2004). Therefore, it is highly difficult to treat cancers with apoptotic resistance because of so many potential targets. In the present work, autophagy induced apoptotic cell death was carried out without using drugs. Autophagy induced by glucose starvation showed a potent apoptotic cell death in drug resistant, apoptotic resistant HL60/ADR cells. Direct apoptosis induction by serum deprivation resulted in weak apoptotic signal compared by autophagy induced apoptosis.

\section{MATERIALS and METHODS}

\section{Materials}

RPMI 1640, RPMI 1640 glucose free media, Fetal Bovine Serum (FBS), octyl- $\beta$-D-glucose, dioleolphosphatidylglycerol, phenylmethylsulfonyl fluoride (PMSF), leupeptin, aprotenin and Uridine Diphosphate glucose (UDP glucose) were from Sigma, St. Louis, MO, USA. SuperSignal West Pico chemiluminescent substrate (Pierce), tissue culture grade penicillin and streptomycin (Gibco Life Technologies, Paisley, U K). C6-NBD-Cer and C6-NBD-SM were from Avanti. Doxorubicin was from (Adriblastina, Pharmacia and Upjohn, Milan, Italy). Anti caspase $3 \mathrm{mAb}$ was from Santa Cruz Biotechnology. Anti BCL-1 and anti BAX mAbs were from Cell Signaling Technology, Inc., Beverly, MA, USA. Anti LC3 mAb was from Affinity BioReagent, Denver, CO, USA. Goat anti $\beta$ actin, goat anti mouse IgG HRP conjugated and mouse anti goat HRP conjugated were from Jackson laboratory Inc. All other chemicals of fine grade, if not mentioned, were obtained from local suppliers.

\section{Cell culture}


The generation of HL 60/ADR cell line was done as mentioned previously (Abdel-Shakor, 2009). Briefly, the parental cell line (HL 60) was continuously cultured in increasing sublethal concentration of doxorubicin up to $580 \mathrm{ng} / \mathrm{ml}$ for 30 days. The obtained drug-resistant HL60/ADR cell line was grown in RPMI 1640 supplemented with $10 \%$ FBS, $1 \%$ penicillin $(50 \mathrm{U} / \mathrm{ml})$, streptomycin $(50 \mu \mathrm{g} / \mathrm{ml})$ in $100 \%$ humidified atmosphere with $5 \% \mathrm{CO}_{2}$ at $37^{\circ} \mathrm{C}$. 48 hours inoculated cells were harvested and $2 \times 10^{6}$ cells were washed twice with PBS, pH 7.2 and incubated in serum free or glucose free (serum free) RPMI medium supplemented with $5 \mu \mathrm{g} / \mathrm{ml}$ human recombinant insulin and transferrin for different time points up to $6 \mathrm{hrs}$.

\section{Measurement of Cer}

Diacylglycerol kinase assay (DGK) for quantitative measurements of Cer was done as described elswere (Bielawska et al., 2001). Briefly $2.5 \times 10^{6}$ HL60/ADR cells were rared in serum free or glucose free RPMI 1640 medium for different time points. Total cellular lipids were extracted as described (Bligh and Dayer, 1959), then dried under Nitrogen gas. The dried lipids were dissolved in $7.5 \%$ octyl- $\beta$-Dglucose, $25 \mathrm{mM}$ dioleolphosphatidylglycerol solution. Lipid micelles were mixed with the reaction buffer containing $3.8 \mu \mathrm{g} / \mu \mathrm{l}$ DGK membrane from DGK-overexpressed E. coli,100 $\mu \mathrm{M}$ ATP and $4 \mu \mathrm{Ci}$ $[\gamma-32 \mathrm{P}]$ ATP (Amersham) in total $100 \mu \mathrm{l}$ volume.The mixture was incubated at $37^{\circ} \mathrm{C}$ for $30 \mathrm{~min}$. Aliquots of extracted lipids were spotted on TLC plates (Whatman, LK6DF Silica gel) and lipids were separated in a solvent system containing chloroform/acetone/methanol/acetic acid/water (10:4:3:2:1, v/v/v/v/v), radioactive lipids, were visualized and quantified by BAS2000 Image Analyzer (Fuji, Japan). Lipid spots corresponding to Cer-phosphate were identified compared with the known standards. Lipid phosphate level was measured compared with the phosphate level of linear concentrations of $\mathrm{NaH}_{2} \mathrm{PO}_{4}$ and then Cer levels were normalized to lipid phosphate levels and expressed as (pmol/nmol phosphate).

\section{Measurements of SMS and GCS activities}

SMS and GCS activities were measured as described previously (Yamaoka et al., 2004) with minor modifications. $5 \times 10^{6}$ cells were homogenized in lysis buffer containing $20 \mathrm{mM}$ Tris-HCL (pH 7.5), 2 mM EDTA, $1 \mathrm{mM}$ PMSF, $2.5 \mu \mathrm{g} / \mathrm{ml}$ leupeptin and $2.5 \mu \mathrm{g} / \mathrm{ml}$ aprotenin. Cells were left on ice for $10 \mathrm{~min}$ and then homogenized by passing 10 times through 27 gauge needle. The homogenates were centrifuged $\left(2500 \mathrm{rpm}, 5 \mathrm{~min}, 4^{\circ} \mathrm{C}\right.$ ). $100 \mu \mathrm{g}$ protein of supernatants were incubated 
with C6-NBD-Cer/phosphatidylcholine (1:10) liposomes $(20 \mu \mathrm{g})$ and 50 $\mu \mathrm{M}$ UDP glucose in buffer containing $10 \mathrm{mM}$ Tris-HCL ( $\mathrm{pH} 7.5$ ), $1 \mathrm{mM}$ EDTA (in total volume $100 \mu \mathrm{l}$ ) for $60 \mathrm{~min}$ at $37{ }^{\circ} \mathrm{C}$. Reaction was stopped by adding $2 \mathrm{ml}$ chloroform: methanol $(2: 1, \mathrm{v} / \mathrm{v})$ and then $900 \mu \mathrm{l}$ of $\mathrm{H}_{2} \mathrm{O}$ and centrifuged at $3000 \mathrm{rpm}$ for $5 \mathrm{~min}$ to separate the phases. The lower phase was collected and the solvent was evaporated. Dried lipids were dissolved in chloroform and aliquots were applied to TLC plates. NBD-lipids were resolved in a solvent system containing chloroform/methanol/12 $\mathrm{mM} \mathrm{MgCl} 2(65 / 25 / 4, \mathrm{v} / \mathrm{v} / \mathrm{v})$, the fluorescence was detected and quantified, (LAS-2000, Fuji, Japan).

\section{Measurments of ASMase and NSMase activities}

ASMase and NSMase activities were assayed based on a previously described method (Okazaki et al., 1989 and Tanaka et al., 1996). Briefly, cells $\left(2.5 \times 10^{6}\right)$ were homogenized in $1 \mathrm{ml}$ lysis buffer containing $10 \mathrm{mM}$ Tris-HCL (pH 7.5), 1 mM EDTA, $1 \%$ Triton X-100, $1 \mathrm{mM}$ PMSF, $10 \mu \mathrm{g} / \mathrm{ml}$ pepstatin and $2.5 \mu \mathrm{g} / \mathrm{ml}$ aprotenin. 30 seconds sonication was done for samples used for ASMase activity determination. Cell lysates was centrifuged at $12,000 \mathrm{x}$ g for $10 \mathrm{~min}$ at 4 ${ }^{\circ} \mathrm{C} .20 \mu \mathrm{g}$ of protein was mixed with the reaction buffer for NSMase activity, containing $100 \mathrm{mM}$ Tris-HCL (pH 7.5), $10 \mathrm{mM} \mathrm{MgCl} 2,5 \mathrm{mM}$ dithiothreitol, $54 \mu \mathrm{M}$ C6-NBD-SM and $0.1 \%$ Triton X-100 ( total volume $100 \mu \mathrm{l}$ ). For ASMase activity, the protein was mixed with the same reaction buffer used for NSMase but containing $100 \mathrm{mM}$ acetate buffer ( $\mathrm{pH}$ 5.0) instead of Tris-HCL and without dithiothreitol (total volume $100 \mu \mathrm{l}$ ). The mixure was incubated for $30 \mathrm{~min}$ at $37^{\circ} \mathrm{C}$; the reaction was stopped by adding $2 \mathrm{ml}$ chloroform/methanol $(2: 1, \mathrm{v} / \mathrm{v})$ and centrifuged at $3,000 \times \mathrm{g}$ for $5 \mathrm{~min}$ to separate the organic and aquas phases. The lower phase was collected and the solvent was evaporated. Dried lipids were dissolved in chloroform and aliquots were then applied to TLC plates. NBD-lipids were resolved in a solvent system containing chloroform/methanol/12 $\mathrm{mM} \mathrm{MgCl} 2(65 / 25 / 4$, v/v/v), the fluorescence was detected and quantified by image analyser, (LAS-2000, Fuji Film, Japan).

\section{Western blotting}

After incubation in (serum free or glucose free media), cells were washed twice in PBS, pH 7.2 and lysed at $4^{\circ} \mathrm{C}$ in $200 \mu$ of lysis buffer containing (30 mM HEPES pH 7.5, $140 \mathrm{mM} \mathrm{NaCl}, 5 \mathrm{mM}$ EDTA, 0.5\% Nonided P40, 0.5\% Triton X-100, $1 \mathrm{mM}$ PMSF and $10 \mu \mathrm{g} / \mathrm{ml}$ pepstatin and $2.5 \mu \mathrm{g} / \mathrm{ml}$ aprotenin). Cell were lysed by disruption through 
15-gauge syringe needle, cellular debris was removed by centrifugation at $10,000 \mathrm{x} \mathrm{g}$ for $10 \mathrm{~min}$ at $4^{\circ} \mathrm{C}$. Protein concentration in the supernatant was determined by BCA protein assay (Pierce, Rockford, Illinois). Aliquots of $45 \mu \mathrm{g}$ of total cell lysates were then separated on $10 \%$ SDS-PAGE. Proteins were transferred to nitrocellulose membranes by BioRad dry electro-transfer blocking with 5\% skim milk in TTBS (TBS with $0.05 \%$ Tween 20 ) Incubation with primary specific antibodies and horseradish peroxidase-conjugated secondary antibodies was performed in blocking solution according to the manufacturers' instructions for $1 \mathrm{~h}$ at room temperature. Immunoreactive bands were visualized by SuperSignal West Pico Chemioluminescent substrate kit. Anti- $\beta \square$ actin goat polyclonal antibody was used for equal loading confirmation. Optical density of protein bands were estimated by Image $\mathbf{J}$ software and then normalized to the density of corresponding $\beta \square$ actin bands, and finally blotted as arbitrary units.

\section{RESULTS}

\section{Autophagy induction by glucose starvation but not by serum deprivation}

In the present study it was found that glucose starvation induced autophagy induction in HL60/ADR cells. Autophagy started after 2 hrs of glucose starvation and gradually increased over the time points, as indicated by the level of LC3II protein (Fig. 1A). In serum deprived cells, there was no detection of LC3II proteins, indicated that no autophagy induction. The percentage of LC3II/ LC3I reached almost $40 \%$ and $70 \%$ after 4 and 6 hrs of glucose starvation respectively (Fig. 1B), whereas there were no detectable changes of this percentage in serum deprived cells. 

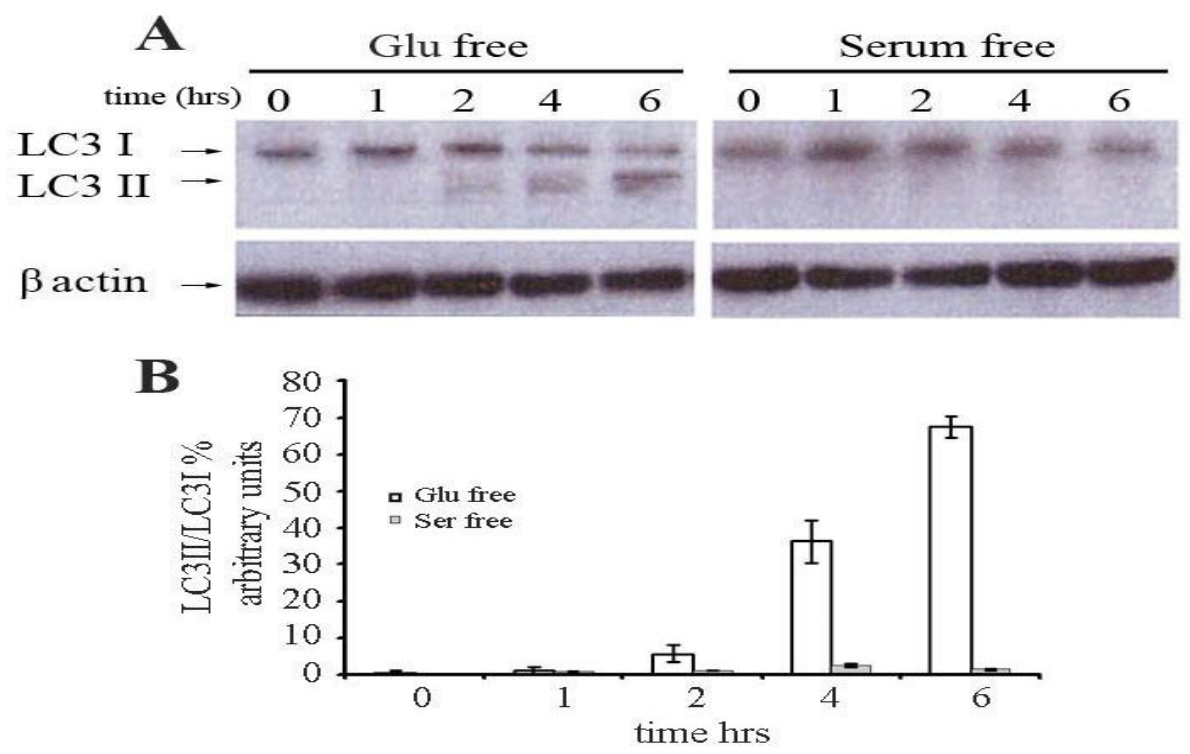

Fig. 1: Induction of autophagy in glucose starved cells but not in serum deprived cells. After exposing cells to glucose free or serum free media for the indicated time points, cells were lysed and immunoblotting detection of the autophagy marker, LC3 protein was carried out, one out of two independent experiments is shown (A). Level of LC3I and II bands was estimated by measuring optical density of each band, and the percentage of LC3II/ LC3I was calculated, shown are means \pm SE (B). $\beta$ actin was used for confirmation of equal loaded protein concentrations.

\section{Effective apoptotic cell death following autophagy induction}

In many cell lines, autophagy was followed by apoptotic cell death after a relatively prolonged time of stress. Here, the apoptotic cell death was investigated in glucose and serum deprivation using caspase 3 cleavage, BCL-1 and BAX protein representation. In glucose starved cells, caspase 3 cleaved, active form was detected after 2 hrs of starvation and increased gradually over the time. The same result was obtained in serum deprived cells, but the level of active caspase 3 was strongly reduced compared with its counterpart of glucose starved cells at the same time points (Fig. 2A). To confirm the effectiveness of autophagy for induction of apoptosis in the drug resistant and apoptosis resistant HL60/ADR, the levels of anti-apoptotic BCL-1 onchogene and pro-apoptotic BAX protein were investigated. Glucose starvation induced an obvious down-regulation of BCL-1 and up-regulation of BAX over the time, whereas in serum deprivation there were almost no 
important changes of both proteins levels (Fig. 2A). Level of active caspase 3 increased to 23 folds higher than its basic level after 6 hrs of glucose starvation compared with almost 8 folds increase in serum deprivation (Fig. 2B). BCL-1 was reduced to 3 folds lower than its basic level after $6 \mathrm{hrs}$ and BAX was increased to almost 10 folds higher than its basic level in glucose starved cells (Figs. 2C, D). Taken together, autophagy induced by glucose starvation was able to induce effective apoptotic cell death in apoptosis resistant, multidrug resistant HL60/ADR.
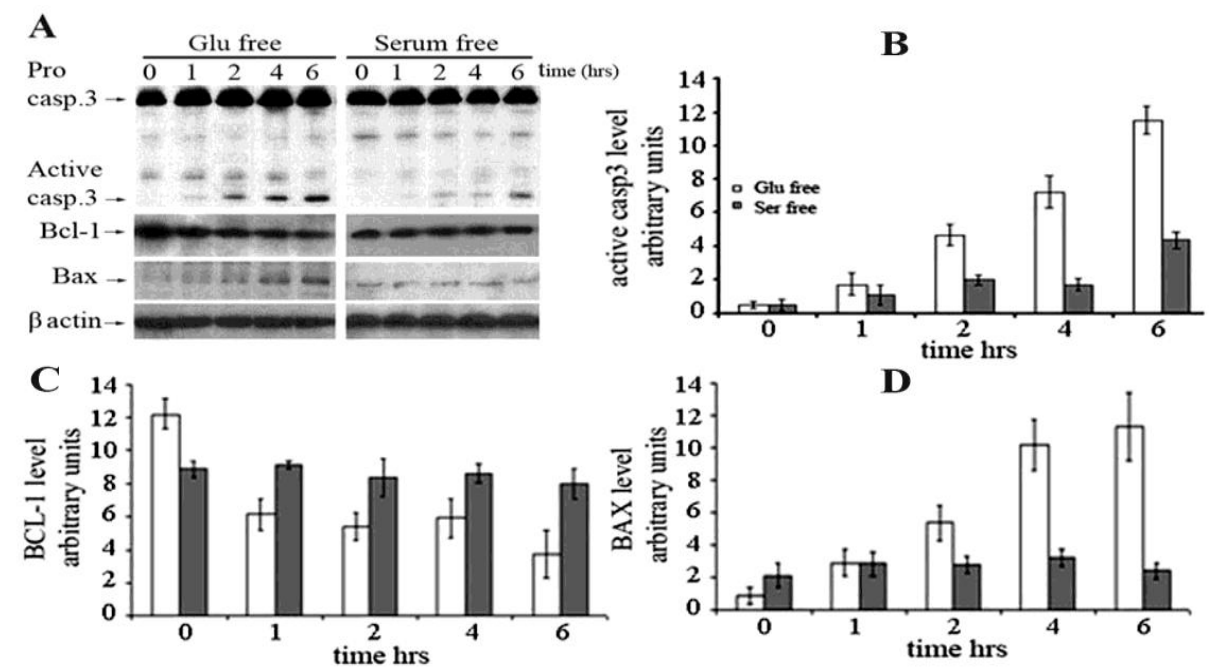

Fig. 2: Glucose starvation induces apoptosis and controlling pro- and anti-apoptotic molecules. Immunoblots of casp.3, BCL-1 and BAX were carried out after cells exposure to glucose free and serum free media, one out of two independent experiments is shown (A). Levels of active casp3 (B), BCL-1 (C) and BAX (D) bands over time points were estimated by measuring optical density of each band and then normalized to the optical density of the corresponding $\beta$ actin band, shown are means \pm SE.$\beta$ actin was used for confirmation of equal loaded protein concentrations.

\section{Elevation of Cer level by glucose starvation:}

After exposure to Glucose or serum free media for different time points, Cer level were measured by DGK assay. There was clearly indication for the increased level of Cer upon autophagy induction, and decreased level of Cer in serum deprivation (Fig. 3A). In glucose free medium, Cer level was increased gradually over time points till $4 \mathrm{hrs}$ and then reached the basic level after 6 hrs. Interestingly, Cer level was 
decreased in serum free medium from till $2 \mathrm{hrs}$ and then gradually reached the basic level (Fig. 3B).

\section{Enzymes responsible for Cer modulation}

Four common sphingolipids metabolizing enzymes were studied in this work; they are SMS, GCS, NSMase and ASMase. It was found that the key enzymes controlling Cer level in both stimuli were SMS, GCS and NSMase, whereas ASMase seemed to slightly decreased in both stimuli. SMS activity was clearly decreased over time points in glucose starvation, whereas in serum deprivation, SMS activity was slightly increased (Figs. 4A, B). With respect to GCS activity in autophagic stimulus, it was slightly decreased over time points, but almost had no change in serum deprivation. NSMase activity was obviously increased in autophagic stimulus but almost had no change in serum deprivation (fig $4 \mathrm{~A}$ and $\mathrm{B}$ ). In conclusion, SMS and GCS activities which use Cer as substrate for building SM and GCer, respectively were obviously decreased upon autophagy, giving the chance for NSMase to accumulate Cer by hydrolyzing of SM. The opposite case was found in apoptosis, where SMS activity was increased, consuming Cer for building SM and at the same time there was no compensation from any of Cer producing enzymes, leading to continuous consumption of Cer.
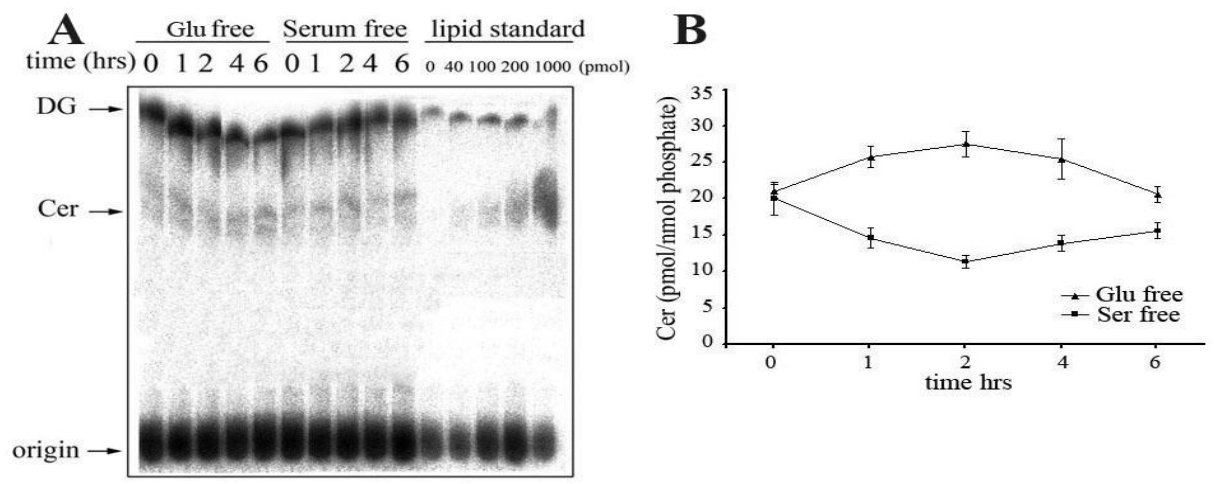

Fig. 3: Elevation of Cer level by glucose starvation and decrease by serum deprivation. Cells were subjected to measuring of Cer levels by DGK assay at the indicated time points. Lipids were spotted on TLC plate, developed and radioactive lipids were imaged as described in methods section (A). Level of Cer was quantified by comparing the density of Cer bands with the Cer standards and expressed as pmol Cer/nmol phosphate (B). 


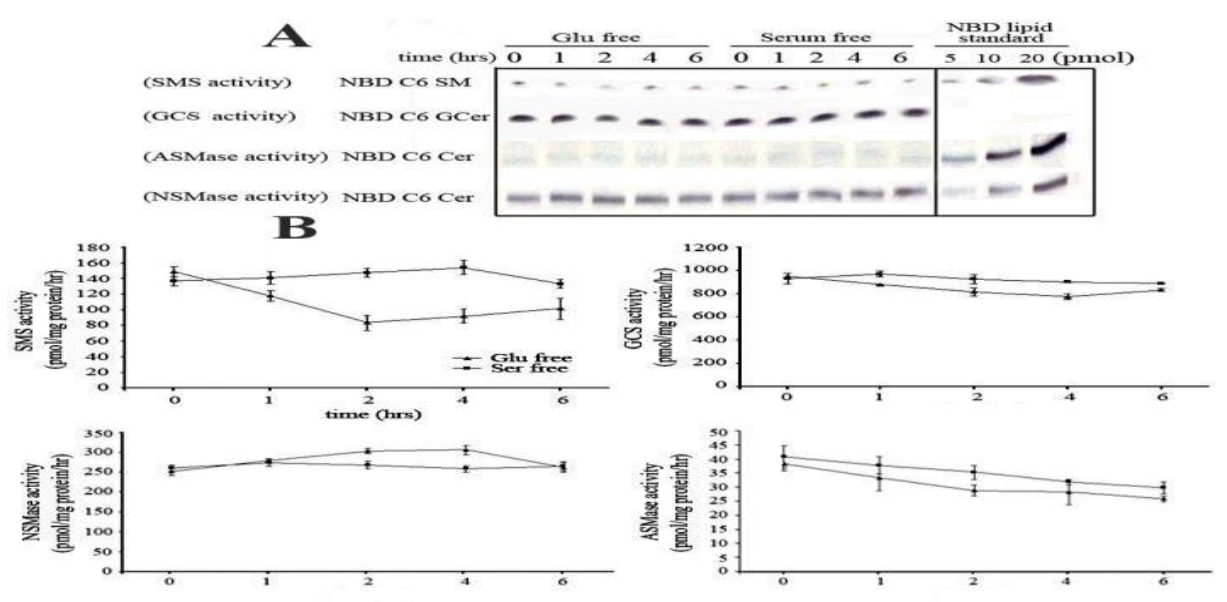

Fig. 4: Glucose starvation elevated Cer level by down-regulation of SMS and GCS activities and up-regulation of NSMase activity. Activities of SMS, GCS, NSMase and ASMase were estimated as described in methods section. Images of the standards and corresponding lipid spots of the resolved lipids are shown (A). The activity of each enzyme over the indicated time points was estimated and expressed as $\mathrm{pmol} / \mathrm{mg}$ protein/hr, shown are means $\pm \mathrm{SE}(\mathrm{B})$.

\section{DISCUSSION}

Considering the fact that apoptosis inducing drugs are to a significant extent correlated with cancer drug resistance, it is reasonable to assume if an agent that kills cancer cells through nonapoptotic pathways may circumvent conventional drug resistance (Ruefli et al., 2000, 2002; Suarez et al., 2003; Ribas et al., 2006). In the case of tumor multidrug resistance (MDR), less Cer levels were detected compared with their sensitive counterparts (Itoh et al., 2003). Low level of Cer in MDR cells has been shown to result from abnormal Cer metabolism by the over expressed enzymes, glucosyl ceramide synthase (GCS) and sphingomyelin synthase (SMS), to elevate the apoptotic threshold and become apoptosis resistant (Bleicher and Cabot, 2002). In the present work, a comparison between serum deprivation, which is a well known autophagy and apoptosis inducers in many cell lines and glucose starvation was carried out. Glucose starvation showed an effective apoptotic cell death preceded by autophagy induction compared with serum deprivation which showed a weak apoptotic signal and was not preceded by autophagy. The first sign for the effective apoptosis 
induction by glucose starvation is the down-regulation of both SMS and GCS activities resulted in elevation of cellular Cer level, as demonstrated in the present results. It seems that autophagy is a pre-request for apoptosis to be effective death mean, at least in MDR, HL60/ADR. Hence, serum deprivation-induced apoptosis did not overcome the low level of Cer, giving a week apoptotic signal. Whereas, glucose starvation-induced apoptosis, which is preceded by autophagy, elevated Cer level and give a stronger apoptotic signal.

It was reported that $\mathrm{Cer}$ is the corner stone for apoptosis and autophagy induction (Daido et al., 2004; Abdel-Shakor, 2009). Also, Cer is one of the components that mediate cross-talk between apoptosis and autophagy (Daido et al., 2004). The present results confirm the role of Cer as a mediator between autophagy, apoptosis and cell death. Hence, the effective apoptosis was only obtained in glucose starvation where Cer level was elevated.

Changes in amino acid concentration in tissues and plasma during fasting are relatively small (Palou et al., 1981). In the current work, glucose starvation was the candidate instead of amino acids starvation to gain more reality, approaching the physiology of starvation occurring in animal tissues. It is now believed that the endocrine system, particularly insulin, manages autophagy regulation in vivo. Liver autophagy is suppressed by insulin and enhanced by glucagon (Mortimore and Pösö 1987). Furthermore, recent Drosophila genetic studies have demonstrated the physiological importance of insulin signaling in vivo (Rusten et al., 2004; Scott et al., 2004). In addition to insulin and amino acid signaling, the involvement of many other factors in autophagy regulation has recently been reported (Codogno and Meijer, 2005). Although autophagy may be a survival mechanism for tumor cells (Lum et al., 2005, Degenhardt et al., 2006, Amaravadi et al., 2007, Karantza-Wadsworth et al., 2007; Mathew et al., 2007), there are many reports that autophagy may act as a tumor suppressor (Hippert et al., 2006, Jin and White 2007; Levine, 2007). For example, monoallelic deletions of Beclin-1 (important autophagic gene) are frequently observed in human breast, ovarian, and prostate cancers (Liang et al., 1999). In conclusion, the present work investigating the role of glucose starvation on autophagy-induced apoptotic cell death as effective mechanism to overcome MDR cells. 


\section{ACKNOWLEDGMENT}

My deep thanks to the group of cell biology, Faculty of Science, Zoology Dept. Alexandria University, Damanhour branch, Damanhour, Egypt for supplementation of DGK membranes.

\section{REFERENCES}

Abdel-Shakor, M., A-B. (2009): Enhancement of apoptotic cell death by dual autophagic stimuli in multidrug resistant human leukemia HL 60/ADR cells. Assiut Univ. J. of Zoology. 38: 11-23.

Amaravadi, R.K.; Yu, D.; Lum, J.J.; Bui, T.; Christophorou, M.A.; Evan, G.I.; Thomas-Tikhonenko, A. and Thompson, C.B. (2007): Autophagy inhibition enhances therapy-induced apoptosis in a Myc-induced model of lymphoma. J. Clin. Invest. 117: 326-336.

Bielawska, A.; Perry, D.K. and Hannun, Y.A. (2001): Determination of ceramides and diglycerides by the diglyceride kinase assay. Anal Biochem. 298: 141-150.

Blagosklonny, M.V. (2004): Prospective strategies to enforce selectively cell death in cancer cells. Oncogene, 23: 2967-75.

Bleicher, R.J. and Cabot, M.C. (2002): Glucosylceramide synthase and apoptosis. Biochim. Biophys. Acta. 1585: 172-178.

Bligh, E.G. and Dayer, W.J. (1959): A rapid method of total lipid extraction and purification. Can. J. Biochem. Physiol. 37: 911-917.

Codogno, P. and Meijer, A.J. (2005): Autophagy and signaling: Their role in cell survival and cell death. Cell Death Differ.12 (Suppl. 2): 1509-1518.

Cuervo, A.M. (2004): Autophagy: In sickness and in health.Trends Cell Biol. 14: 70-77.

Daido, S.; Kanzawa, T.; Yamamoto, A.; Takeuchi, H.; Kondo, Y. and Kondo, S. (2004): Pivotal role of the cell death factor BNIP3 in ceramide induced autophagic cell death in malignant glioma cells. Cancer Res. 64: 4286-4293.

Degenhardt, K.; Mathew, R.; Beaudoin, B.; Bray, K.; Anderson, D.; Chen, G.; Mukherjee, C.; Shi, Y.; Gelinas, C.; Fan, Y.; Nelson, D.A.; Jin S. and White, E. (2006): Autophagy promotes tumor cell survival and restricts necrosis, inflammation, and tumorigenesis. Cancer Cell 10: 51-64.

Hannun, Y.A.; Luberto, C. and Argraves, K.M. (2001): Enzymes of sphingolipid metabolism: from modular to integrative signaling. Biochemistry, 40: 4893-4903. 
Hersey, P. and Zhang, X.D. (2003): Overcoming resistance of cancer cells to apoptosis. J. Cell Physiol. 196: 9-18.

Hippert, M.M.; O'Toole, P.S. and Thorburn, A. (2006): Autophagy in cancer: Good, bad, or both? Cancer Res. 66: 9349-9351.

Itoh, M.; Kitano, T.; Watanabe, M.; Kondo, T.; Yabu, T.; Taguchi, Y.; Iwai, K.; Tashima, M.; Uchiyama, T. and Okazaki, T. (2003): Possible role of ceramide as an indicator of chemoresistance: decrease of the ceramide content via activation of glucosylceramide synthase and sphingomyelin synthase in chemoresistant leukemia. Clin. Cancer Res. 8: 415-423.

Jin, S. and White, E. (2007): Role of autophagy in cancer: Management of metabolic stress. Autophagy, 3: 28-31.

Kabeya, Y.; Mizushima, N.; Ueno, T.; Yamamoto, A.; Kirisako, T.; Noda, T.; Kominami, E.; Ohsumi, Y. and Yoshimori, T. (2000): LC3, a mammalian homologue of yeast Apg8p, is localized in autophagosome membranes after processing. EMBO. 19: 5720-5728.

Karantza-Wadsworth, V.; Patel, S.; Kravchuk, O.; Chen, G.; Mathew, R.; Jin, S. and White, E. (2007): Autophagy mitigates metabolic stress and genome damage in mammary tumorigenesis. Genes \& Dev. 21: 1621-1635.

Klionsky, D.J. (2005): The molecular machinery of autophagy: Unanswered questions. J. Cell Sci. 118: 7-18.

Klionsky, D.J. (2007): Autophagy: From phenomenology to molecular understanding in less than a decade. Nat. Rev. Mol. Cell Biol. 8(11): 931-937.

Levade, T.; Malagarie-Cazenave, S.; Gouaze, V.; Segui, B.; Tardy, C.; Betito, S.; Andrieu-Abadie, N. and Cuvillier, O. (2002): Ceramide in apoptosis: a revisited role. Neurochem. Res. 27: 601-607.

Levine, B. (2007): Cell biology: Autophagy and cancer. Nature, 446: 745-747.

Levine, B. and Klionsky, D.J. (2004): Development by self-digestion: Molecular mechanisms and biological functions of autophagy. Dev. Cell 6: 463-477.

Liang, X.H.; Jackson, S.; Seaman, M.; Brown, K.; Kempkes, B.; Hibshoosh, H. and Levine, B. (1999): Induction of autophagy and inhibition of tumorigenesis by beclin 1. Nature, 402: 672-676.

Longley, D.B. and Johnston, P.G. (2005): Molecular mechanisms of drug resistance. J. Pathol. 205: 275-292. 
Lum, J.J.; Bauer, D.E.; Kong, M.; Harris, M.H.; Li, C.; Lindsten, T. and Thompson, C.B. (2005): Growth factor regulation of autophagy and cell survival in the absence of apoptosis. Cell, 120: 237-248.

Maceyka, M.; Payne, S.G.; Milstien, S. and Spiegel, S. (2002): Sphingosine kinase, sphingosine-1-phosphate, and apoptosis. Biochim. Biophys. Acta, 1585: 193-201.

Mathew, R.; Kongara, S.; Beaudoin, B.; Karp, C.M.; Bray, K.; Degenhardt, K.; Chen, G.; Jin, S. and White, E. (2007): Autophagy suppresses tumor progression by limiting chromosomal instability. Genes \& Dev. 21: 1367-1381.

Mathias, S.; Pena, L.A. and Kolesnick, R.N. (1998): Signal transduction of stress via ceramide. Biochem. J. 335: 465-480.

Merrill, A.H.J. (2002): De novo sphingolipid biosynthesis: a necessary, but dangerous, pathway. J. Biol. Chem. 277: 25843-25846.

Mizushima, N. (2005): The pleiotropic role of autophagy: from protein metabolism to bactericide. Cell Death Differ. 2:1535-1541.

Mizushima, N. and Klionsky, D.J. (2007): Protein turnover via autophagy: Implications for metabolism. Annu. Rev. Nutr. 27: 19-40.

Mizushima, N.; Yamamoto, A.; Hatano, M.; Kobayashi, Y.; Kabeya, Y.; Suzuki, K.; Tokuhisa, T.; Ohsumi, Y. and Yoshimori, T. (2001): Dissection of autophagosome formation using Apg5-deficient mouse embryonic stem cells. J. Cell Biol. 152: 657-668.

Mortimore, G.E. and Pösö, A.R. (1987): Intracellular protein catabolismand its control during nutrient deprivation and supply. Annu. Rev. Nutr. 7: 539-564

Okazaki, T.; Bell, R.M. and Hannun, Y.A. (1989): Sphingomyelin turnover induced by vitamin D3 in HL-60 cells. Role in cell differentiation. J. Biol. Chem. 264: 19076-19080.

Palou, A.; Remesar, X.; Arola, L.; Herrera, E. and Alemany, M. (1981): Metabolic effects of short term food deprivation in the rat. Horm. Metab. Res. 13: 326-330.

Pommier, Y.; Sordet, O.; Antony, S.; Hayward, R.L. and Kohn, K.W. (2004): Apoptosis defects and chemotherapy resistance: molecular interaction maps and networks. Oncogene, 23: 2934-49.

Ribas J.; Bettayeb, K.; Ferandin, Y.; Knockaert, M.; Garrofé-Ochoa, X.; Totzke, F.; Schächtele, C.; Mester, J.; Polychronopoulos, P.; Magiatis, P.; Skaltsounis, A.L.; Boix, J. and Meijer, L. (2006): 
7-Bromoindirubin-3- oxime induces caspase-independent cell death. Oncogene, 25: 6304-6318.

Riboni, L.; Viani, P.; Bassi, R.; Prinetti, A. and Tettamenti, G. (1997): The role of sphingolipids in the process of signal transduction. Prog. Lipid Res. 36: 153-195.

Ruefli, A.A.; Smyth, M.J. and Johnstone, R.W. (2000): HMBA induces activation of a caspase-independent cell death pathway to overcome P-glycoprotein- mediated multidrug resistance. Blood 95: 2378-2385.

Ruefli, A.A.; Bernhard, D.; Tainton, K.M.; Kofler, R.; Smyth, M.J. and Johnstone, R.W. (2002): Suberoylanilide hydroxamic acid (SAHA) overcomes multidrug resistance and induces cell death in P-glycoprotein-expressing cells. Int J Cancer. 99: 292-298.

Rusten, T.E.; Lindmo, K.; Juhasz, G.; Sass, M.; Seglen, P.O.; Brech, A. and Stenmark, H. (2004): Programmed autophagy in the Drosophila fat body is induced by ecdysone through regulation of the PI3K pathway. Dev. Cell 7: 179-192.

Scott, R.C.; Schuldiner, O. and Neufeld, T.P. (2004): Role and regulation of starvation-induced autophagy in the Drosophila fat body. Dev. Cell, 7: 167-178.

Shintani, T. and Klionsky, D.J. (2004): Autophagy in health and disease: A double-edged sword. Science 306: 990-995.

Stavrovskaya, A.A. (2000): Cellular mechanisms of multidrug resistance of tumor cells. Biochemistry (Mosc) 65: 95-106.

Suarez, Y.; Gonzalez, L.; Cuadrado, A.; Berciano, M.; Lafarga, M.; Munoz, A. and Kahalalide, F. (2003): A new marine-derived compound induces oncosis in human prostate and breast cancer cells. Mol. Cancer Ther. 2: 863-872.

Tanaka, K.; Ogawa, N.; Asanuma, M.; Kondo, Y. and Nomura, M. (1996): Relationship between cholinergic dysfunction and discrimination learning disabilities in Wistar rats following chronic cerebral hypoperfusion. Brain Res. 729: 55-65.

Wang, C.W. and Klionsky, D.J. (2003): The molecular mechanism of autophagy. Mol. Med. 9: 65-76.

Yamaoka, S.; Miyaji, M.; Kitano, T.; Umehara, H. and Okazaki, T. (2004): Expression cloning of a human cDNA restoring sphingomyelin synthesis and cell growth in sphingomyelin synthase-defective lymphoid cells. J. Biol. Chem. 279: 1868818693. 